\title{
CERBE
}

Center for Relationship Banking and Economics Working Paper Series

\section{Urbanization And International Migration From Africa}

Giovanni Ferri and

Roshan Borsato

\section{Working Paper No. 29}

July 2018 


\title{
Urbanization And International Migration From Africa
}

\author{
Giovanni Ferri and Roshan Borsato
}

\begin{abstract}
Climate change exacerbates desertification forcing millions of rural people to urbanize, especially in developing countries. Our quantitative analysis across African countries highlights migrants' two typical sequential moves: i) people escape from villages to cities; ii) through cities' enabling settings, some of them emigrate to developed countries. We find that: i) previous lower fresh water availability - our climate-related proxy - and drops in GDP's agricultural share in Sub-Sahara seem to boost subsequent urbanization: ii) previously heightened urbanization subsequently inflates emigration rates. Thus, policies to combat land impoverishment/desertification would help both the environment and easing the stress that migration casts on societies' balance.
\end{abstract}

JEL Classification: F22; O15; O18; O55; Q54; R14; R23.

Keywords: desertification, climate change, urbanization, international migration.

\section{Introduction}

Migration is certainly not a new phenomenon in human history: from the beginning of history there have been cases of exodus of entire communities from one place to another one, in search of what we can generically define a decent life.

Migration represents a survival strategy used by people to tackle all kind of negative events that affect their lives; in this sense we have many types of migration: temporary, permanent, circular, voluntary or forced, national and international. Events such as drought and desertification have always caused the migration of entire communities. What we can emphasize today is that the intensity and frequency of these environmental phenomena is indeed escalating: the situation is problematic in Africa, where $70 \%$ of the population depends on agriculture, which is a source of both food and income. Drier soils are more exposed to wind and water erosion: consequences of this are the reduction of soil fertility, less food production and less vegetation for pastures. The decline in income and rising poverty, even in relative terms, are to be considered determinants for migration from rural areas (Leighton, 2006). 
Along this line, it is also recognized that natural disasters could affect conflict and job opportunities and, as such, indirectly impact mass migration (Naudé, 2010).

We should also consider the possibility that internal migration often represents a first step in a migratory trajectory, where the second step is represented by international emigration (King et al., 2008). In this case we can expect that a first phase of the internal migratory wave will intensify urbanization in a country and then, in the second phase, as a result, international emigration will also intensify.

On this basis we propose two main hypotheses. First, the degree of urbanization increased more in countries suffering climate-related negative shocks and/or conflicts and/or other types of instability. Second, the emigration rate grew more in countries previously experiencing higher increases in the degree of urbanization.

Our analysis focuses on the countries of Africa. We explore first the determinants of urbanization and then investigate the determinants of the migratory flows towards the OECD countries. Therefore, urbanization and emigration rates are our dependent variables, respectively, in the regression relating to the first move and in the estimate concerning the second move. Our explanatory variables span from those linked to environmental factors (such as, for example, the availability of fresh water), to those related to economic and social strife (political economic and financial stability, ethnic and religious fragmentation).

The rest of the paper is structured as follows. Section 2 contains a short review of the relevant literature and, following the logical sequence of our argument, its building blocks consist of: 'From Climate Change to Migration' (sub-section 2.1), 'Migration as a Coping Strategy' (sub-section 2.2), 'Desertification and Internal Rural-Urban Migration' (sub-section 2.3), and 'From Urbanization to Emigration' (sub-section 2.4). In section 3, we formulate our two main research hypotheses, describe the data and the methodology used in the empirical analysis. In section 4 we expose and comment our main results. Finally, section 5 concludes summarizing our main findings and discussing their chief policy implications.

\section{Literature Background}

\subsection{From Climate Change to Migration}

In recent years there has been a growing interest in the possible impact of climate change on migration. In 2009 estimates provided for a massive exodus of people by 2050 (some hypothesized 25 million, others were up to a billion) and identified climate change as one of the leading causes of the phenomenon (IOM, 2009). 
Many experts have not hesitated to classify these statistics as mere speculations. But, all considered, these studies, beside their scientific precision, have certainly helped to attract more attention, especially by politicians, on the probable implications of climate change on migratory phenomena.

Despite the lack of precision in the data there is no doubt that an increasing number of areas of planet earth are becoming uninhabitable due to factors such as, just to name a few, climate change, deterioration of agricultural land, desertification and water pollution. Notably the number of natural disasters has more than doubled over the last two decades and in 2008 more than 20 million people were forced to migrate due to environmental disasters (OCHA/IDMC, 2009).

The rise in global temperatures (forecasts refer to an increase of between 2 and 5 degrees Celsius by the end of this century) could have a decisive impact on global migration flows.

Migration linked to climate change does not really represent a new phenomenon in the history of humankind: already in the past nomadic peoples and shepherds frequently moved in search of lands suited to their needs. This evidently corresponded to their survival needs. However, it is only in the last 20 years that the international community has begun to identify and recognize the link between climate change and human mobility. From 1990 the Intergovernmental Panel on Climate Change warned that the greatest impact of climate change could be on human migration - with millions of displaced people due to coastal erosion, coastal flooding and severe droughts (IPCC, 1990). Along the same lines, the International Migration Organization (IOM) stated in 1992: "Large numbers of people are moving as a result of environmental degradation that has increased dramatically in recent years. The number of such migrants could rise substantially as larger areas of the earth become uninhabitable as a result of climate change" (IOM, 1992).

However, the relationship between climate change and migration does not find unanimous consensus within the scientific community. The literature on environmental migration tends to divide into two large groups: (1) the "minimalists", suggesting that the environment is only a contextual factor to many others in the decisions to migrate and (2) the maximalists, holding, on the contrary, that the environment is the determining factor that forces people to move towards other places. In this sense it is worth clarifying that climate change in itself is not the cause of migratory phenomena, but can produce those environmental effects that make it hard, if not impossible, to remain in a given territory. It is expected that climate change will increase global temperatures, will result in more intense and volatile rainfall and, at the same time, less frequent precipitations for some geographical areas. Moreover, prolonged droughts will occur leading, in extreme cases, to desertification and cause sudden and unexpected natural disasters such as violent floods. Some environmental changes, such as hurricanes and earthquakes, occur without a warning: they require people to move quickly. Others, like desertification, kick in slowly, almost imperceptibly: they give people time to ponder how to 
react better and how to set their lives by choosing among various options, including migrating to other places. Migration in these cases is undoubtedly an adaptation strategy (Bardsley \& Hugo, 2010). While the adverse effects of climate change are felt all over the world, the less developed regions are particularly affected as their economies and institutions lack the necessary adaptation skills and thus are unable to deploy strategies and models to counteract climate-related shocks. Some estimates, for example, put at 262 million the people that were affected by climatic disasters every year over 20002004 and of these more than 98\% lived in developing countries (UNDP, 2008). Environmental disasters affected particularly Southeast Asia, sub-Saharan Africa and the small islands of the world: indeed, $70 \%$ of the people who lost their lives due to these tragic events were in Asia (IOM, 2008). In such framework, the International Migration Organization has developed the following definition of environmental migrants: "Environmental migrants are persons or groups of persons who, for compelling reasons of sudden or progressive change in the environment that adversely affects their lives or living conditions, are obliged to leave their habitual homes, or choose to do so, either temporarily or permanently, and who move either within their country or abroad". ${ }^{1}$

The IOM definition offers an all-inclusive view of the migratory phenomenon by encompassing both individual movements and movements of groups of people; it allows migration to be either temporary or permanent. It is interesting to note that migration, according to the IOM definition, can take place both within national boundaries and beyond regional boundaries (international movement is usually a less frequent option, also because it requires significant economic endowments). Finally, according to this definition, the causes can stem both from sudden natural calamities - floods, storms, floods or from slow evolving phenomena such as drought, famine and desertification.

\subsection{Migration as a Coping Strategy}

Migration remains a survival strategy used by people affected by natural disasters (Hugo, 2009). It is often described as a continuum that goes from entirely voluntary migration to an obliged and inevitable movement - the latter is, for example, the case of people forced to flee armed conflicts, violence, violation of human rights, (either natural or human-made) catastrophes. W can, however, define as forced migration also that which occurs in the case of climatic events that pose severe threats to the life of human beings. Researchers agree that environmental migration, mainly that caused by sudden natural disasters, is a form of "forced migration" (Hugo \& Gemenne, 2008). However, the features of migration can also vary over time: in cases of hurricanes or other violent and sudden disasters, migration is first labelled as compelled. Once the danger of life ceases and the conditions

1 http://www.iom.int/jahia/webdav/shared/shared/mainsite/about_iom/en/council/94/MC INF 288.pdf. See also Chazalnoël \& Ionesco, (2016). 
for a possible return are established, people can freely decide to continue to reside in their new place of residence rather than return to their original location. In such cases, the migration from obliged turns into voluntary as justified by a cost/benefit analysis of the situation (Myers et al., 2008).

Another fascinating profile concerns the duration of environmental migration and the criteria for distinguishing temporary from permanent migration. On this point, there is no consensus: some speak of six months for temporary migration, while others emphasize the lack of willingness to return to the places of origin as a condition for permanent migration. Still, others consider "short-term" any migration from the place of habitual residence to another country for a period of at least three months but less than one year (Findley, 1994).

Part of the literature claims that the decision to migrate permanently depends on the type of disaster occurred. In a nutshell, disasters with slow onset, such as desertification, lead to permanent migration while sudden events lead to short-term migration. It is estimated that only a small part of migrants (up to 30\%) choose to move permanently (Black et al., 2011).

A special case is represented by circular migration (which remains, in any case, within the category of temporary migrations). It is a common phenomenon in areas subject to environmental disasters. Migrations are permanent when areas are hit by flooding so strong that they cause loss of crops and homes. Instead, migratory movements are circular when people migrate to find temporary jobs. In fact, unskilled workers prefer jobs for a short period as they can return home for the harvest season (Kayastha \& Yadava, 1985). This way of living and moving makes the so-called circular migration. The latter is adopted as an adaptation strategy in many developing countries. This is due, on the one hand, to the fact of having some relatives present in the destination areas and, on the other hand, due to the belief that the earth would recover its productivity (Naik et al., 2007). Other forms of migration strategy include cases in which some family members permanently migrate to other destinations leaving other family members at home. This happens, for instance, in the Sahel region of West Africa where young people are sent away to make money (IOM, 2014a).

Migrations can be classified according to whether they are national or international. Firstly, it is assumed that environmental post-disasters migration occurs within national boundaries, particularly towards the nearest destinations (Piguet et al., 2012). This conclusion is supported by studies both on developing countries and on developed ones. An analysis of the population after the devastation of Hurricane Katrina has shown the emergence of migration to neighbouring states that had not been damaged by the hurricane and were able to provide shelter (Myers et al., 2008).

There is a strong consensus that displaced people due to environmental disasters remain within their national borders (Ferris, 2007; Hugo, 2009). This, at the same time, is in stark contrast to the people 
who migrate to escape persecution and armed conflict; conflicts, in particular, force people to leave not only their communities but also their countries (Ferris, 2008).

It is interesting to note that environmental disasters can inhibit long-distance shifts and international migration. Findley's study of the drought in Mali between 1982 and 1989 found changes in migration patterns in times of crisis. In particular, the Sahel traditionally has two forms of migration: (1) shortcycle migration, whereby younger males, especially those from more impoverished families, go to nearby cities for poorly paid jobs (women usually find work as servants), (2) long-cycle migration, which is characterized by having a long duration rather than a long distance. In any case, it has among other destinations countries such as France, Gabon, and Senegal (these movements could, in fact, be considered long-cycle circulators since people often remain abroad for two to three years and continuously send remittances). Long-cycle migration can take years of planning and therefore according to these studies it is not the best answer, or at least the most used one, in cases of crop shortages due to drought-dependent reasons (Findley, 1994).

Also in the Sahel, in the period between 1983 and 1985, there was an exceptional drought and most families to overcome the crisis had no other means than migration to other places: families send some of their members to other countries looking for a source of income (Pederson, 1995).

\subsection{Desertification and Internal Rural-Urban Migration}

Desertification consists of land degradation in dry, semi-arid and sub-humid dry areas due to climatic and human activities that reduce soil fertility and the ability of vegetation to thrive (UNCCD, 1994). Events such as drought and desertification have always caused the migration of entire communities; what we need to emphasize today is that the intensity and frequency of these phenomena is indeed escalating (Ionesco et al., 2016). This leads to significant environmental problems, but also economic and social issues (Zander et al., 2016).

Notably, the situation is problematic in Africa, where $70 \%$ of the population depends on agriculture, which is a source of both food and income. In 2009, in particular, the drought severely hit the countries of East Africa (Kenya, Ethiopia, Uganda, Somalia) for 5 years in a row affecting up to 23 million people (Reuters, 2009). Among the factors that certainly contribute to desertification, we need to mention human activity: for example, the excessive exploitation of land and water or also deforestation to expand cultivated land (Drigo \& Marcoux, 1999). In turn, among the climatic factors we can mention the high temperatures and low rainfall (even the extreme variability of rainfall can be considered among the causes of desertification) (Herrmann \& Hutchinson, 2006).

In this sense it should be noted that drier soils are more exposed to wind and water erosion: consequences of this are the reduction of soil fertility, less food production and less vegetation for 
pastures. All this imperils income sources and food security: for these reasons, agricultural households are forced to diversify their sources of income (Climate Vulnerable Forum, 2016). Also in this case, one of the survival strategies is undoubtedly migration (IOM, 2014b).

The decline in income and rising poverty, even in relative terms, are to be considered determinants for migration from rural areas (Leighton, 2006). Families that can count on an income sufficient to meet their needs are not, on the contrary, inclined to migrate.

As said, in many cases, migration tends to be temporary as migrants tend to return to their places of origin as soon as possible to engage in agricultural activity, using for this purpose the money earned to support investments for their agricultural projects. Migration, in these cases, is a circumstantial phenomenon: the desire to return home after a certain period, the desire not to move away from the place of origin, determines, in fact, a local migration, in any case within the national borders (very often from the village of origin to the nearest urban centre, or at most beyond the borders of the neighbouring state) (UNFCCC, 2007). However, the prolonged absence of men from the countryside makes rehabilitating the land difficult since the people who remain are mainly women and children. In such framework, remittances play a pivotal role for communities: indeed, in 1993, they played a crucial role for $75 \%$ of household income and, at the same time, contributed to finance schools, post offices and other social centres and services (Vargas-Lundias et al., 2007).

Some studies suggest that when rural communities are affected by drought and desertification, they can react by adopting international migration, particularly when it is easy to cross neighbouring borders (IPCC, 2001). In Latin America, for example, it has been demonstrated that drought and desertification play a decisive role in migratory flows from rural areas to other rural areas, and from rural areas to urban areas; this concerns both migration within the country and movements towards the United States (Leighton, 1997). In Latin America desertification affects about two thirds of the region and poor management of the territory contributes to soil erosion (Leighton, 2006); all these factors lead, as a result, to a reduction in household income and a consequent increase in poverty. The common strategy adopted in these cases is an international migration to the United States also thanks to a strong social network that facilitates migratory flows and their impact - in some cases a family member already resides in the USA making it more attractive to migrate there (Munshi, 2003). Some researches underline the crucial role of drought (and desertification) in international migration. Cai et al. (2016) find a significant link between rising temperatures and global migration but only for countries that are highly dependent on agriculture. Also, Coniglio \& Pesce (2015) find that the occurrence of adverse climatic events in origin countries has significative direct and indirect effects on out-migration from poor to rich countries. 
To be sure, however, some authors find no significant role for climate. Based on a survey conducted at Tuvalu, for instance, Mortreux \& Barnett (2009) show that the vast majority of potential migrants do not consider climate change as a possible reason to leave the country. Naudé (2010) also reports that natural disasters have no significant effects on international migration in Sub-Saharan African countries. However, it was argued that these studies did not consider the possible indirect impact of the climate through differences in income and other channels. For example, in the data used by Mortreux \& Barnett (2009), migrants may not be aware of the possibility that climate change implicitly contributes to socio-economic shocks that, in turn, affect migration, and therefore do not mention climate change as a reason for leaving when they are interviewed. While discussing the insignificant effects of natural disasters on migration, Naudé (2010) also recognizes that natural disasters could affect conflict and job opportunities and, as such, indirectly impact mass migration. As well, Beine \& Parsons (2013) do not find evidence of direct impacts of climate anomalies on international migration but only an indirect effect through international wage differentials.

On their part, Barrios et al. (2006) investigate the role that climatic change has played in the pattern of urbanization in sub-Saharan African countries compared to the rest of the developing world. Their results suggest that climatic change, as proxied by rainfall, has acted to change urbanization in subSaharan Africa but not elsewhere in the developing world. They also argue that this link has become stronger since decolonization, which often simultaneously led to lifting of legislation prohibiting the free internal movement of native Africans.

\subsection{From Urbanization to Emigration}

A strand of the literature links internal migration and international emigration. Indeed, King \& Skeldon (2010) contend that the interdisciplinary field of migration studies is inappropriately split into internal and international migration, characterised by different literatures, concepts, methods and policy agendas. They conclude that considerable potential exists for integrating the study of internal and international migration, at both the theoretical and the empirical level. A case in point is the possibility that internal migration often represents a first step in a whole migration trajectory, where the second step is international emigration (King et al., 2008). In this case we may expect that a firststage of internal migratory wave will intensify urbanization in a country and then, in the secondstage, international emigration will also intensify.

As King et al. (2008) describe, this two-stage structure is viewed as the most logical sequence in the migration literature. Through the first stage, indeed, rural-origin migrants are enabled to acquaint first with the urban setting of their home country before undertaking a successive out-migration abroad. Urbanization allows movers to spend a first period in a job so to gather the financial endowment and 
contacts required to emigrate. Possibly the city targeted by the internal migration is itself a point of departure for international migration. This type of internal-to-international stepwise migration is testified in the literature, e.g., for Turkey (King, 1976), Thailand (Skeldon, 2006) and Mexico (Cornelius, 1992; del Rey Poveda, 2007; Lozano-Ascencio et al., 1999; Zabin \& Hughes, 1995).

In other words, irrespectively of whether this was planned ex ante or it just happens ex post, urbanization can be viewed as serving like a platform for migrating overseas.

A further aspect to be considered about the African countries that are the object of our empirical study is the type of urbanization. In general, it is believed that there is a positive link between urbanization and economic growth (Henderson, 2005). However, Africa as a continent experienced the unusual phenomenon of urbanization without growth (Fay \& Opal, 2000; Fox, 2012). In addition, the social mobility of the slum residents had been even lower than the economic one which implied that the slums were actually poverty traps rather than the places of hope as it was predicted by the modernization hypothesis (Fox, 2014). Fox (2014) calls this “disjoint modernization". In turn, the condition of African slums may be a further push factor for the rural people who moved there to try to continue their journey abroad.

\section{Hypotheses, Data and Methodology}

\subsection{Hypotheses}

The previous discussion and survey of the literature leads us to formulate the two main hypotheses we want to test:

HYPOTHESIS 1: The degree of urbanization increased more in African countries suffering climaterelated negative shocks and/or conflicts and/or other types of instability.

HYPOTHESIS 2: The emigration rate grew more in African countries previously experiencing higher increases in the degree of urbanization.

\subsection{Data}

Our data comes from the World Bank and other external databases. Specifically, we consider the following two main dependent variables:

i) URBANIZE_90_00 measuring the increase in the degree of urbanization in a country between 1990 and 2000, the ratio between the value in 2000 and that in 1990 (source: our calculations on the percentage of urban population share as derived from the UN Population Division, World Urbanization Prospects, 2014 revision); 
ii) EMIGRATE_00_05 measuring the increase in the total emigration rates to OECD countries, 2000 and 2005/06, the ratio between the value in 2005/06 and that in 2000 (source: our calculations on data published by the OECD).

In turn, the explanatory variables we will use in our regression analyses are the following:

1) FRESHWATER_90 measuring the renewable internal freshwater resources per capita (cubic meters) in the country in 1990;

2) SUBSAHARA, a dummy valued 1 for the Sub-Saharan countries, i.e. all the African countries excluding Algeria, Egypt, Libya, Morocco, South Sudan, Sudan and Tunisia;

3) GNIPC_90 measuring the Gross National Income per capita in 1990 (source: World Bank, Development Indicators, various issues);

4) ICG_RAT_90_00 measuring the change between 1990 and 2000 of a composite indicator of political, financial and economic risk, the ratio between the value in 2000 and that in 1990 (the scale of values of the indicator is as follows: Very high risk from 00.0 to 49.5 ; High risk from 50.0 to 59.5; Moderate risk from 60.0 to 69.5 ; Low risk from 70.0 to 79.5 ; Very low risk from 80.0 to 100 ) (source: ICRG Risk Rating);

5) DISASTER, a graduated dummy measuring the number of years between 1990 and 2000 in which at least a disaster occurred in the country (source: OFDA/CRED International Disaster Database: http://www.cred.be/emdat - Université Catholique de Louvain - Brussels - Belgium);

6) FAMINE, a graduated dummy measuring the number of years between 1990 and 2000 in which at least a famine occurred in the country (source: OFDA/CRED International Disaster Database);

7) CONFLICT measuring the number of people (in millions) affected by conflicts in the country over 1990-2000 (source: OFDA/CRED International Disaster Database);

8) LPOPUL, logarithm of the number of inhabitants in millions in 2000 (source: World Bank, Development Indicators, various issues);

9) AGRISH_80_90 measuring the change in the value added in agriculture (as a \% of GDP), the ratio between the value in 1990 and that in 1980 (source: World Bank, Development Indicators, various issues);

10) AGRISH_SUB given by the product of AGRISH_80_90 and SUBSAHARA;

11) ETHNIC_FRACT measuring the extent of ethnic fractionalization in a country (source: Alesina et al., 2003);

12) LANG_FRACT measuring the extent of language fractionalization in a country (source: Alesina et al., 2003);

13) RELIG_FRACT measuring the extent of religious fractionalization in a country (source: Alesina et al., 2003); 
14) RELIG_SUB given by the product of RELIG_FRACT and SUBSAHARA.

Table 1 reports the usual descriptive statistics for each of the variables.

The choice of explanatory variables is partly suggested by the literature review. The "disasters" variable was inserted because a current of this literature underlined that migration can be a consequence of natural disasters (Hugo, 2009, Hugo \& Gemenne, 2008). Other authors pointed out that desertification and drought, which in turn cause famine, are the cause of permanent migration (Black, 2011). Indeed, this thesis, also supported by the IPCC in 2001, led us to include, among our variables, also the availability of fresh water and famine. Along this line we know that drought, and desertification in general, played a fundamental role in migrations from rural areas to urban villages in Latin America (Leighton, 1997).

Others underline that often international migration is linked to conflicts and social political (in)stability (Ferris, 2008, Black, 2011). This brought us to consider conflicts and ethnic and religious fragmentation, that in African countries are often the cause of strong political, social and religious conflicts, as important variables. Moreover, the choice to put the gross domestic product is justified instead by the fact that part of the literature states that the reduction of wages, and the consequent growth of poverty (even relative), are to be considered determinants for migration from rural areas (Leighton, 2006). Finally, as a significant link between rising temperatures and global migration has been found for countries that are highly dependent on agriculture (Cai et al., 2016), we have also included the variable "agriculture" in our analysis, defined as the percentage of the weight of agriculture in the gross domestic product.

Following the proposal by Alesina et al. (2003), the indexes of fractionalization of population in a country - typically, we refer to ethnic, language and religious fractionalization - are viewed as important characteristics of the country also in its relationships with the other countries. For instance, Giménez-Gómez et al. (2017) show that ethnic fractionalization has a positive impact on migration flows from Africa to Europe for the period 1990-2014. In turn, Shilpi et al. (2014) find that language fractionalization and religious fractionalization are also important determinants of migration in Nepal. On his part, studying migration from Africa, Marfouk (2008) finds that all three forms of fractionalization expand the brain drain phenomenon.

\subsection{Methodology}

Our methodology relies on estimating two cross section regressions having as dependent variable, respectively, URBANIZE_90_00 in the first set of regressions and EMIGRATE_00_05 in the second set of regressions. 
Specifically, the regressions are estimated via Ordinary Least Squares with standard errors robust to heteroschedasticity (by White's correction).

To reduce the risk of endogeneity and/or reverse causality our independent variables, where possible, are pre-dated with respect to the years over which we measure the dependent variable. This means that, for instance, in the first set of regressions the main climate-related variable, FRESHWATER_90, is measured as the level in 1990 while the dependent variable, URBANIZE_90_00, is calculated as the change between 1990 and 2000. By the same token, in the second set of regressions the chief explanatory variable, URBANIZE_90_00, is the change over 1990-2000 while the dependent variable, EMIGRATE_00_05, is calculated as the change between 2000 and 2005/6.

\section{Main Results}

The main results from our regressions offer some support to Hypothesis 1 and a stronger support to Hypothesis 2. Let's examine them in the order.

Regarding the factors associated with the extent of urbanization, the most general specification (Table 2, column 1) finds that, indeed, our climate-related proxy (Freshwater_90) significantly impacts the degree of urbanization. In particular, the higher Freshwater_90 the lower the increase in urbanization in the country. Also, an improvement in the ICG_RAT_90_00 - i.e., less risk in the country - links with less intense urbanization. Finally, the extent of urbanization between 1990 and 2000 has risen more in Sub-Saharan Africa than in the rest of the continent.

Table 2, column 2, reports an intermediate specification where most of the insignificant regressors have been dropped. Here the effects commented for column 1 are confirmed and a new interesting evidence emerges suggesting that, among the Sub-Saharan countries, those where the share of agriculture in GDP increased more between 1980 and 1990 experienced less intense urbanization in the period 1990-2000.

However, due to lacking observations for some variables, the evidence of columns 1 and 2 uses only 29 countries. If we drop some of the other marginally significant variables and so manage to have 41 countries in our regression (Table 2, column 3) the situation changes. First, Freshwater_90 turns out statistically insignificant and only the Sub-Saharan effect persists. Moreover, the R-square drops from beyond 0.40 to just 0.09 and the regression model becomes less reliable as evidenced by the fact that the $\mathrm{F}$ test is now passed only at the $10 \%$ confidence level, while in columns 1 and 2 it was passed at the $1 \%$ level of confidence. Therefore, we should conclude that, possibly because of the quality of our data, we find only partial confirmation of our Hypothesis 1. 
However, our greatest interest rests with the determinants of increasing emigration. Here the results seem to comfortably confirm that the countries which had experienced more intense urbanization between 1990 and 2000 did have higher rises in their emigration rates to OECD countries between 2000 and 2005/2006.

Column 1 of Table 3 reports the most general specification where various regressors are not statistically significant. We try to refine the specification in column 2 where some of the insignificant independent variables are omitted. However, we will focus our comment only on column 3, showing the most parsimonious model. Here, all of the regressors are statistically significant and the model has a good fit, as testified by its high $\mathrm{F}$ statistics. The most interesting variable to us is URBANIZE_90_00 whose coefficient is positive and highly significant. This suggests that between 2000 and 2005/2006 the emigration rate rose more in the countries that had experienced more heightened urbanization between 1990 and 2000, which confirms our Hypothesis 2.

Among the other regressors, we find that the growth of the emigration rate was smaller in larger countries - the negative and significant coefficient of LPOPUL. Of the three fractionalization variables, only RELIG_FRACT turns out significant and with a positive coefficient. This means that migration rates rose more over the observation period in countries having more diversity in terms of the composition of the population by religious type. However, the fact that RELIG_SUB exhibits a negative and significant effect, with a coefficient which almost matches that of RELIG_FRACT, suggests at the same time that this effect of religious fractionalization on migration was driven by the countries of North Africa.

\section{Conclusions}

In the light of the above results, we have highlighted, with our data analysis, a main point: there seems to be a link, on the one hand, between climatic changes and urbanization and, on the other hand, between urbanization and international emigration.

We argued that there is continuity between the two different stages of migration. Indeed, there are factors, including environmental ones, that lead people to move from villages to urban centers. Then, only at a later stage, from there, if conditions permit and if sufficient funds have been collected, some of those who urbanized will be able to venture into the secondary migration, that to developed countries. It is important to underline how our research finds that our climate-related proxy (Freshwater_90) seems to impact the degree of subsequent urbanization. Notably, the higher Freshwater_90, the lower the increase in urbanization in the country between 1990 and 2000. Also, in the ICG_RAT_90_00 - i.e., less risk in the country - links with less intense urbanization. Finally, the extent of urbanization between 1990 and 2000 has risen more in Sub-Saharan Africa than in the 
rest of the continent. This must be correlated with what is analyzed in table 2, from which clearly emerges that, among the sub-Saharan countries, those where the share of agriculture in GDP dropped more between 1980 and 1990 experienced more intense urbanization in the period 1990-2000. This finding allows us to tell that if the land is not degraded and if the soil is maintained productive, allowing people to have a stable source of income, we could experience, as a result, a lower degree of urbanization and, in turn, a lower percentage of emigration. In addition, policies to improve the situation in the deprived slums of Africa could help reduce that internal migration turns into international emigration.

In conclusion, our analysis helps us to understand how climate factors, and those related to social stability, can be considered fundamental at the onset of the migratory phenomena. This causality should represent a strong incentive for political authorities, policy makers and institutions of all kind, to invest in the African countries - and particularly in the Saharan ones -, from where the most substantial migratory flows begin. All this stresses the urgency of intervening in those areas by investing in land recovery, helping communities to have political and social stability, which is often determined by many factors, including the environmental ones. Doing so could mean providing a solution, even partial, to migrations that, according to some estimates, could bring up to 25 million people to move to developed countries, with dramatic human, social and economic costs, both for the people who migrate and for host communities (IOM, 2009). 


\section{References}

Alesina A., A. Devleeschauwer, W. Easterly, S. Kurlat \& R. Wacziarg, 2003. Fractionalization, J. Econ. Growth,8: 155-194.

Bardsley, D.K. \& G.J. Hugo, 2010. Migration and climate change: Examining thresholds of change to guide effective adaptation decision-making. Popul. \& Environm., 32(2): 238-262.

Barrios, S., L. Bertinelli \& E. Strobl, 2006. Climatic change and rural-urban migration: The case of sub-Saharan Africa, J. Urban Econ., 60: 357-371.

Beine, M. \& C. Parsons 20135. Climate factors as determinants of international migration, The Scandinav. J Econ., 117(2): 723-767.

Black, R., W. Neil Adger, N.W. Arnell, S. Dercon, A. Geddes \& D.S.G. Thomas, 2011. The effect of environmental change on human migration. Glob. Environm. Change, 21(S1): S3-S11.

Cai, R., S. Feng, M. Oppenheimer \& M. Pytlikova, (2016). Climate variability and international migration: The importance of the agricultural linkage, J Environm Econ \& Manag 79: 135-151.

Chazalnoël, M.T. \& D. Ionesco, 2016. Defining climate migrants: Beyond semantics. International Organization for Migration weblog, 6 June. Available from https://weblog.iom.int/definingclimate-migrants-\%E2\%80\%93-beyond-semantics.

Climate Vulnerable Forum, 2016. Climate Change and Labour: Impacts of Heat in the Workplace, Issue Paper Available from http://environmentalmigration.iom.int/climate-change-and-labourimpacts-heat-workplace-0

Coniglio, N.D. \& G. Pesce, 2015. Climate variability and international migration: An empirical analysis, Environm. \& Develop. Econ., 20(4): 434-468.

Cornelius, W., 1992. From sojourners to settlers: the changing profile of Mexican immigration to the United States, in Bustamante, J.A., C.W. Reynolds \& R. Hinojosa-Ojeda (eds.) US-Mexico Relations: Labor Market Interdependence. Stanford: Stanford University Press.

del Rey Poveda, A., 2007. Determinants and consequences of internal and international migration: the case of rural populations in the south of Veracruz, Mexico, Demogr. Res., 16(10): 287-314.

Drigo, R. \& A. Marcoux, 1999. Population dynamics and the assessment of land use changes and deforestation, FAO, Rome.

Fay, M. \& C. Opal, 2000. Urbanization without growth: A not so uncommon phenomenon. Policy Research Working Paper No. 2412, Washington, DC: The World Bank.

Fox, S., 2012. Urbanization as a global historical process. Theory and evidence from Sub-Saharan Africa, Population and Development Review, 38(2): 285-310.

Fox, S., 2014. The Political Economy of Slums: Theory and Evidence from Sub-Saharan Africa, World Development, 54, 191-203.

Findley, S.E., 1994. Does drought increase migration? A study of migration from rural Mali during the 1983-1985 Drought, Internat. Migr. Rev., 28(3): 539-53.

Ferris, E., 2007. Making sense of climate change, natural disasters and displacement: a work in progress (lecture), Brookings Institution, Washington.

Ferris. E., 2008, Displacement, natural disasters and human rights, Brookings Institution, Washington, DC.

Giménez-Gómez, J.M., Y.M. Walle \& Y.Z. Zergawu, 2017. Trends in African migration to Europe: Drivers beyond economic motivations, Discussion Papers, Center for European, Governance 
and Economic Development Research, No. 330, Center for European, Governance and Economic Development Research, cege, Georg-August-Universität Göttingen, Göttingen.

Henderson, J.V., 2005. Urbanization and growth, Handbook of economic growth. Vol. 1. Elsevier: 1543-1591.

Herrmann, S. \& C. Hutchinson, 2006. Links between land degradation, drought, and desertification, Johnson, P.M., K. Mayrand \& M. Paquin (eds.), Governing Global Desertification, Ashgate Press, London.

Hugo, G. 2009. Migration, development and environment, IOM, Geneva.

Hugo, G., O. Dun \& F. Gemenne, 2008. Defining environmental migration, Forced Migrat. Rev., $31: 10-11$.

International Organization for Migration - IOM, 2014a. IOM Outlook on Migration, Environment and Climate Change. IOM, Geneva.

International Organization for Migration - IOM, 2014b, Migration, Environment and Climate Change: Evidence for Policy (MECLEP) Glossary. IOM, Geneva. Available at https://publications.iom.int/books/migration-environment-and-climate-change-evidencepolicy-meclep-glossary.

International Organization for Migration - IOM, 2009. Environment and Climate Change: Assessing The Evidence, Geneva.

International Organization for Migration - IOM, 2008. World Migration Report 2008: Managing Labour Mobility in the Evolving Global Economy, Geneva. http://www.iom.int/jahia/webdav/shared/shared/mainsite/about_iom/en/council/94/MC_INF_ 288.pdf.

International Organization for Migration - IOM, 1992. Migration and the Environment, IOM and the Refugee Policy Group (RPG), Geneva.

Intergovernmental Panel on Climate Change - IPCC, 2014. Future Climate Changes, Risks and Impacts. Available at http://www.ipcc.ch/ipccreports/tar/wg2/index.php?idp=450

Intergovernmental Panel on Climate Change - IPCC, 2001. Climate Extremes and Migration, Human Dimensions, Working Group II: Impacts, Adaptation and Vulnerability. Available at www.ipcc.ch/ipccreports/tar/wg2/index.php?idp=450.

Intergovernmental Panel on Climate Change - IPCC, 1990. First Assessment Report, Cambridge University Press, Cambridge.

Ionesco, D., D. Mokhnacheva \& F. Gemenne, 2016. Atlas of Environmental Migration. Routledge, London.

Kayastha, S.L. \& R.P. Yadava, 1985. Flood induced population migration in India: a case study of Ghaghara Zone, Population redistribution and development in South Asia, Kosinski, L., K. Elahi \& D. Reidel (eds.), Dordrecht, Netherlands: 79-88.

King, R., 1976. The evolution of international labour migration movements concerning the EEC, Tijdschrift voor Economische en Sociale Geografie, 67(2): 66-82.

King, R. \& R. Skeldon, 2010. 'Mind the gap!' Integrating approaches to internal and international migration, J. Ethnic \& Migrat. Stud. 36(10): 1619-1646.

King, R., R. Skeldon \& J. Vullnetari, 2008. Internal and international migration: Bridging the theoretical divide, University of Sussex - Sussex Centre for Migration Research, w.p. No. 52. 
Leighton, M., 2006. Desertification and migration, in Johnson, P.M., K. Mayrand \& M. Paquin (eds.): Governing Global Desertification, Ashgate Press, London, UK: 43-58.

Leighton, M., 1997. Environmental degradation and migration: The U.S.-Mexico case study, US Congressional Commission on Immigration Reform, Washington, DC.

Lozano-Ascencio, F., B. Roberts \& F. Bean, 1999. The interconnections of internal and international migration: the case of the United States and Mexico, in Pries, L. (ed.) Migration and Transnational Social Spaces. Aldershot: Ashgate, 138-61.

Marfouk, A., (2008). The African brain drain: scope and determinants, in 'The African Brain DrainManaging the Drain: Working with the Diaspora', Proceedings of the Conference of Rectors, Vice Chancellors and Presidents of African Universities, Association of African Universities, Accra: QualiType Ltd.: 1-36.

Mortreux, C. \& J. Barnett, 2009. Climate change, migration and adaptation in Funafuti, Tuvalu. Glob. Environ. Change 19(1): 105-112;

Munshi, K., 2003. Networks in the modern economy: Mexican migrants in the U.S. labour market, Quart. J. of Econ. 118(2): 549- 599.

Myers, C., J. Singelmann \& T. Slack, 2008. Social vulnerability and migration in the wake of disaster: the case of Hurricanes Katrina and Rita, Popul. \& Environm., 29(6): 271-291.

Naik, A, E. Stigter, F. Laczko, 2007. Migration, development and natural disasters: Insights from the Indian Ocean tsunami, IOM Migration Research Series (30), IOM, Geneva.

Naudé, W., 2010. The determinants of migration from Sub-Saharan African countries. J. Afr. Econ. 19 (3), 330-356.

OCHA/IDMC, 2009, Monitoring disaster displacement in the context of climate change - Findings of a study by the United Nations Office for the Coordination of Humanitarian Affairs and the Internal Displacement Monitoring Centre.

Pederson, J., 1995. Drought, migration and population growth in the Sahel - the case of the Malian Gourma, 1900-1991, Popul. Stud., 49 (1): 111-126.

Piguet, E., A. Pecoud, P. de Guchteneire, 2012, Migration and climate change: An overview, Refugee Survey Quart., 30(3): 1-23.

Reuters, 2009. East Africa Drought in Fifth Year, Millions Hungry, Sept. 29.

Shilpi, F., P. Sangraula \& Y. Li, 2014. Voting with their feet? access to infrastructure and migration in Nepal. The World Bank, Policy Research Working Paper No. 7047, September.

Skeldon, R., 2006. Interlinkages between internal and international migration and development in the Asian region, Population, Space and Place, 12(1): 15-30.

United Nations Framework Convention on Climate Change - UNFCCC, 2007. Climate Change Impacts, Vulnerability and Adaptation in Developing Countries, Bonn, Germany.

United Nation Development Program - UNDP, 2008. Human Development Report 2007-2008, Fighting climate change: Human solidarity in a divided world, United Nations Development Programme (UNDP), Palgrave Macmillan, New York.

Vargas-Lundias, R., M. Lanly, M. Viallareal \& M. Osorio, 2007. International migration, remittances and rural development, IFAD \& FAO. Available at: www.ifad.org/pub/remittances/migration.pdf.

Zabin, C. \& S. Hughes, 1995. Economic integration and labour flows: stage migration in farm labour markets in Mexico and the United States, Internat. Migrat. Rev., 29(2): 395-422. 
Zander, K., A. Surjan \& S. Garne, 2016. Exploring the effect of heat on stated intentions to move. Climatic Change, 138(1): 297-308. 
Table 1. Descriptive Statistics

\begin{tabular}{|c|c|c|c|c|c|c|}
\hline Variable name & No. obs. & Mean & Median & Stand. dev. & Min & Max \\
\hline URBANIZE_90_00 & 54 & 1.16087 & 1.1475 & 0.2467715 & 0.800 & 2.756 \\
\hline EMIGRATE_00_05 & 53 & 1.31547 & 1.2500 & 0.3632044 & 0.714 & 2.000 \\
\hline FRESHWATER_90 & 51 & 13340.27 & 2466.3 & 27839.990 & 28.600 & 153401.8 \\
\hline SUBSAHARA & 54 & 0.870370 & 1 & 0.3390495 & 0 & 1 \\
\hline GNIPC_90 & 46 & 1969.130 & 1310 & 1782.951 & 410 & 9110 \\
\hline ICG_RAT_90_00 & 42 & 1.252491 & 1.153785 & 0.2873659 & 0.813187 & 2.139014 \\
\hline DISASTER & 42 & 0.714286 & 0 & 1.153694 & 0 & 5 \\
\hline FAMINE & 42 & 0.595238 & 0 & 0.9122346 & 0 & 4 \\
\hline CONFLICT & 42 & 3.412914 & 0.09001 & 8.0829200 & 0 & 45.30239 \\
\hline POPUL & 42 & 16.31190 & 10 & 19.53601 & 1.1 & 100 \\
\hline AGRISH_80_90 & 37 & 1.002658 & 0.99195 & 0.2612247 & 0.330466 & 1.515167 \\
\hline AGRISH_SUB & 37 & 0.813925 & 0.95096 & 0.4391022 & 0 & 1.515167 \\
\hline ETHNIC_FRACT & 52 & 0.630471 & 0.71910 & 0.2489503 & 0 & 0.93020 \\
\hline LANG_FRACT & 51 & 0.592953 & 0.70050 & 0.2965126 & 0.010300 & 0.92270 \\
\hline RELIG_FRACT & 53 & 0.459983 & 0.55440 & 0.2785901 & 0.002800 & 0.86030 \\
\hline RELIG_SUB & 53 & 0.446613 & 0.55440 & 0.2925400 & 0 & 0.86030 \\
\hline
\end{tabular}

(*) The data sources of each variable are spelled out in the text. 
Table 2. Regression on the Determinants of Urbanization

\begin{tabular}{|c|c|c|c|}
\hline \multirow[b]{2}{*}{ Explanatory variables } & \multicolumn{3}{|c|}{ Dependent variable: Urbanize_90_00 } \\
\hline & $(1)$ & $(2)$ & $(3)$ \\
\hline \multirow[t]{2}{*}{ Freshwater_90 } & $-1.52 \mathrm{e}-06^{*}$ & $-1.53 \mathrm{e}-06^{* *}$ & $-1.68 \mathrm{e}-06$ \\
\hline & $(7.88 \mathrm{e}-07)$ & $(6.60 \mathrm{e}-07)$ & $(1.01 \mathrm{e}-06)$ \\
\hline \multirow[t]{2}{*}{ Icg_rat_90_00 } & $-0.146 * *$ & $-0.139 * *$ & $-0.222 * *$ \\
\hline & $(0.064)$ & $(0.053)$ & $(0.091)$ \\
\hline \multirow[t]{2}{*}{ Disaster } & -0.003 & - & - \\
\hline & $(0.027)$ & - & - \\
\hline \multirow[t]{2}{*}{ Famine } & 0.010 & - & - \\
\hline & $(0.023)$ & - & - \\
\hline \multirow[t]{2}{*}{ Conflict } & -0.004 & -0.005 & - \\
\hline & $(0.003)$ & $(0.003)$ & - \\
\hline \multirow[t]{2}{*}{ Subsahara } & $0.346^{*}$ & $0.372 * *$ & $0.128 * *$ \\
\hline & $(0.190)$ & $(0.18)$ & $(0.056)$ \\
\hline \multirow[t]{2}{*}{ Agrish_80_90 } & 0.149 & 0.157 & - \\
\hline & $(0.134)$ & $(0.124)$ & - \\
\hline \multirow[t]{2}{*}{ Agrish_Sub } & -0.250 & $-0.269 *$ & - \\
\hline & $(0.160)$ & $(0.156)$ & - \\
\hline \multirow[t]{2}{*}{ Constant } & $1.097 * * *$ & $1.078 * * *$ & $1.353 * * *$ \\
\hline & $(0.218)$ & $(0.193)$ & $(0.117)$ \\
\hline Observations & 29 & 29 & 41 \\
\hline R-squared & 0.465 & 0.460 & 0.092 \\
\hline $\mathrm{F}$ test & $12.39 * * *$ & $15.71 * * *$ & $2.30 *$ \\
\hline
\end{tabular}

Note: The table reports regressions coefficients. In parentheses are robust standard errors. $(*)$ : coefficient significant at $10 \%$ confidence level; $(* *)$ : coefficient significant at $5 \%$ confidence level; $(* * *)$ : coefficient significant at less than $1 \%$ confidence level. The $\mathrm{F}$ test tests whether the hypothesis that all the included regressor coefficients are jointly zero can be rejected (*: at 10\%; **: at 5\%; ***: at $1 \%$ level of significance). 
Table 3. Regression on the Determinants of Increasing Emigration

\begin{tabular}{|c|c|c|c|}
\hline \multirow[b]{2}{*}{ Explanatory variables } & \multicolumn{3}{|c|}{ Dependent variable: Emigrate_00_05 } \\
\hline & $(1)$ & $(2)$ & $(3)$ \\
\hline \multirow[t]{2}{*}{ Urbanize_90_00 } & $1.036^{*}$ & $1.090^{*}$ & $0.269 * * *$ \\
\hline & $(0.538)$ & $(0.555)$ & $(0.089)$ \\
\hline \multirow[t]{2}{*}{ GNI_PC_90 } & $2.52 \mathrm{e}-05$ & $-1.67 e-06$ & - \\
\hline & $(4.35 \mathrm{e}-05)$ & $(3.52 \mathrm{e}-05)$ & - \\
\hline \multirow[t]{2}{*}{ Icg_rat_90_00 } & -0.290 & -0.107 & - \\
\hline & $(0.331)$ & $(0.304)$ & - \\
\hline \multirow[t]{2}{*}{ Disaster } & 0.035 & - & - \\
\hline & $(0.057)$ & - & - \\
\hline \multirow[t]{2}{*}{ Famine } & 0.069 & - & - \\
\hline & $(0.093)$ & - & - \\
\hline \multirow[t]{2}{*}{ Conflict } & -0.023 & -0.019 & - \\
\hline & $(0.013)$ & $(0.014)$ & - \\
\hline \multirow[t]{2}{*}{ Subsahara } & -0.3586 & -0.120 & 0.152 \\
\hline & $(0.406)$ & $(0.247)$ & $(0.173)$ \\
\hline \multirow[t]{2}{*}{ Lpopul } & $-0.155^{* *}$ & $-0.134 * *$ & $-0.113 * *$ \\
\hline & $(0.059)$ & $(0.053)$ & $(0.045)$ \\
\hline \multirow[t]{2}{*}{ Ethn_fract } & 0.531 & - & - \\
\hline & $(0.600)$ & - & - \\
\hline \multirow[t]{2}{*}{ Lang_fract } & $0.316^{*}$ & $0.437 *$ & - \\
\hline & $(0.180)$ & $(0.253)$ & - \\
\hline \multirow[t]{2}{*}{ Relig_fract } & $4.285^{* *}$ & $3.902 * *$ & $2.222 * * *$ \\
\hline & (1.783) & (1.851) & $(0.525)$ \\
\hline \multirow[t]{2}{*}{ Relig_Sub } & $-3.903 * *$ & $-3.565^{* *}$ & $-1.982 * * *$ \\
\hline & (1.856) & (1.900) & $(0.562)$ \\
\hline \multirow[t]{2}{*}{ Constant } & 0.242 & 0.119 & $0.944 * * *$ \\
\hline & $(0.815)$ & $(0.820)$ & (0.199) \\
\hline Observations & 37 & 37 & 37 \\
\hline R-squared & 0.442 & 0.401 & 0.275 \\
\hline $\mathrm{F}$ test & $3.11 * * *$ & $4.31 * * *$ & $7.48 * * *$ \\
\hline
\end{tabular}

Note: The table reports regressions coefficients. In parentheses are robust standard errors. $(*)$ : coefficient significant at $10 \%$ confidence level; $(* *)$ : coefficient significant at $5 \%$ confidence level; $(* * *)$ : coefficient significant at less than $1 \%$ confidence level. The $\mathrm{F}$ test tests whether the hypothesis that all the included regressor coefficients are jointly zero can be rejected $(*:$ at $10 \%$; **: at $5 \%$; ***: at $1 \%$ level of significance). 